Шаповал Л. А. / Власний досвід ехокардіографічного оцінювання ступеня асиметрії атріовентрикулярного...

https://doi.org/10.30702/ujcvs/19.3609/060051-062

УДК 616.12-07;611.127

Шаповал Л. А. ${ }^{1}$, лікар-кардіолог дитячий

Руденко Н. М., ${ }^{1,2}$, д-р мед. наук, проф., заступник директора з наукової роботи кардіологічного профілю, завідувач кафедри дитячої кардіології та кардіохірургії

Довгань О. М. ${ }^{1}$, д-р мед. наук, ст. наук. співробітник, завідувач відділу біотканинної реконструктивної хірургії

Ємець І. М. ${ }^{1}$, д-р мед. наук, проф., директор

${ }^{1}$ ДУ «Науково-практичний медичний центр дитячої кардіології та кардіохірургії МОЗ України», м. Київ, Україна

${ }^{2}$ Національна медична академія післядипломної освіти імені П. Л. Шупика, м. Київ, Україна

\title{
Власний досвід ехокардіографічного оцінювання ступеня асиметрії атріовентрикулярного з'єднання в пацієнтів з різними анатомічними варіантами атріовентрикулярної комунікації при виборі оптимальної тактики хірургічного лікування
}

\begin{abstract}
Резюме. Серед великої кількості анатомічних варіантів атріовентрикулярної комунікації (АВК) трапляються випадки з нерівномірним атріовентрикулярним (AB) з'єднанням, що асоціюються з гіпоплазією лівого (ЛШ) або правого (ПШ) шлуночків і визначаються як незбалансовані форми. Ступінь дисбалансу впливає як на тип, так і на ризик оперативного втручання. Основним завданням у визначенні дисбалансу в АBK $€$ прогнозування здатності ЛШ підтримувати системний кровообіг, що є важливим при виборі оптимальної тактики хірургічного лікування. Сучасною тенденцією в діагностиці цієї складної вади є об'єднання нових концепцій з раніше існуючими критеріями в єдине ціле, щоб допомогти обрати оптимальний шлях хірургічного лікування.
\end{abstract}

Мета - проаналізувати основні ехокардіографічні (ЕхоКГ) показники, які визначають дисбаланс у пацієнтів з різними анатомічними варіантами АВК і провести кореляцію цих показників з розмірами, що характеризують «геометрію шлуночків» відповідно до обраної хірургічної тактики.

Матеріали та методи. За період із січня 2014 по грудень 2018 року обстежено та проведено хірургічне лікування 279 пацієнтам з різними анатомічними варіантами АВК. Для визначення анатомічних особливостей вади використовували такі ЕхоКГ-показники, як модифікований індекс атріовентрикулярного клапана (mAVVI), кут припливу між ПШ та ЛШ (RV/LV inflow angle), індекс припливу ЛШ (LVII), обчислювали кінцево-діастолічну площу ЛШ та ПШ, кінцево-систолічну площу ЛШ та ПШ, лінійні розміри обох шлуночків та АВ-клапанів.

Результати. Порівнюючи зазначені ЕхоКГ-показники дисбалансу з вимірами «геометрії шлуночків», вста-

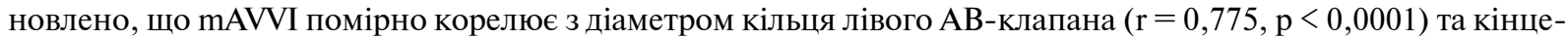
во-діастолічною площею ЛШ $(\mathrm{r}=0,531, \mathrm{p}<0,0001)$ і слабо корелює з діаметром кільця правого АВ-клапана $(\mathrm{r}=0,23, \mathrm{p}=0,0013)$ та $з$ кінцево-діастолічною площею ПШ $(\mathrm{r}=0,240, \mathrm{p}=0,001)$; RV/LV inflow angle помірно корелює з діаметром кільця лівого AB-клапана та діаметром кільця правого $\mathrm{AB}-$ клапана $(\mathrm{r}=0,861$, $\mathrm{p}<0,0001$ та $\mathrm{r}=0,775, \mathrm{p}<0,0001$ відповідно) й суттєво не корелює з кінцево-діастолічною площею ЛШ та ПШ. Виявлена слабка кореляція LVII з кінцево-діастолічною площею ЛШ $(\mathrm{r}=0,101, \mathrm{p}=0,880)$ та слабка кореляція LVII з діаметром кільця лівого AB-клапана $(r=0,175, p=0,021)$, відсутня кореляція LVII з кінцево-діастолічною площею ПШ та діаметром кільця правого АВ-клапана.

Висновок. ЕхоКГ-показники дисбалансу мають слабку або помірну кореляцію з вимірами «геометрії шлуночків», що свідчить про те, що жоден з цих показників не повинен використовуватися самостійно при визначенні ступеня збалансованості та вибору тактики хірургічного лікування в пацієнтів з різними анатомічними варіантами АВК.

Ключові слова: незбалансована атріовентрикулярна комунікація, модифікований індекс атріовентрикулярних клапанів, індекс припливу лівого шлуночка, кут припливу між правим і лівим шлуночками.

Вступ. Серед великої кількості анатомічних варіантів атріовентрикулярної комунікації (АВК) у 10-15\% випадках вада характеризується несиметричним атріовентрикулярним (AB) з'єднанням та визначається як 
незбалансована форма [7]. Ступінь дисбалансу впливає як на тип, так і на ризик оперативного втручання. Якщо дисбаланс спільного АВ-клапана виражений, вибір хірургічної тактики є однозначним. Однак у випадках з помірно вираженим дисбалансом спільного $\mathrm{AB}-$-клапана вирішити, яка хірургічна тактика $є$ оптимальною, залишається складним завданням. Критерії, що визначають межу, при якій доцільність і ризик двошлуночкової корекції є виправданим, невідомі [12, 13].

Головна діагностична проблема визначення дисбалансу обумовлена наміром порівняти ліві та праві структури серця за подібністю. Проте дисбаланс може бути наявний на різних анатомічних рівнях. Певний ступінь асиметрії на одному рівні не означає, що такий самий рівень асиметрії буде наявний і на інших анатомічних рівнях [10].

Дисбаланс в АВК характеризується не тільки відсутністю симетрії в розмірах (анатомічний дисбаланс), а й у розподілі кровотоку між легеневим та системним кровообігом (фізіологічний дисбаланс). Деякі анатомічні особливості, такі як розмір дефекту міжшлуночкової перегородки (ДМШП), дефекту міжпередсердної перегородки (ДМПП), зміщення міжпередсердної перегородки (МПП) та/або міжшлуночкової перегородки (МШП), мають значно більший вплив на розподіл між системним і легеневим кровообігом, ніж наявність або відсутність симетрії в розмірах між правими та лівими структурами серця. Крім того, фізіологічний дисбаланс може сприяти розвитку анатомічної асиметрії [10]. Основним завданням під час визначення дисбалансу АВК є прогнозування здатності ЛШ підтримувати системний кровообіг, що є важливим при виборі оптимального шляху хірургічного лікування. Тенденцією на сьогодні є об'єднання нових концепцій та вже описаних діагностичних критеріїв в єдине ціле, що допоможе визначити оптимальний шлях хірургічного лікування дітей з такою складною вродженою патологією серця.

Мета - проаналізувати основні ехокардіографічні (ЕхоКГ) показники, що визначають дисбаланс у пацієнтів з різними анатомічними варіантами АBK i провести кореляцію цих показників з вимірами, що характеризують «геометрію шлуночків» відповідно до обраної хірургічної тактики.

Матеріали та методи. За період із січня 2014 по грудень 2018 року в НПМЦДКК МОЗ України обстежено та проведено хірургічне лікування 279 пацієнтам 3 різними анатомічними варіантами АВК. Під час проведення первинного ЕхоКГ обстеження, морфометричний аналіз спільного АВ-клапана виконували рутинно і враховували в діагностичній категоризації обстежених пацієнтів при визначенні відповідної групи й тактики хірургічного лікування. 3279 пацієнтів у 245 $(87,8 \%)$ було діагностовано збалансовану АВК (I група), у решти 34 (12,2 \%) - визначено певний ступінь дисбалансу спільного АВ-клапана (II група), 27 (9,8 \%) 3 яких мали незбалансовану праводомінантну АВК, а 7 (2,5 \%) - незбалансовану ліводомінантну АВК.

Середній вік пацієнтів на момент корекції становив $12,7 \pm 3,5$ місяця (діапазон від 27 днів до 8,7 року). Середня вага $-7,45 \pm 2,7$ кг (діапазон від 3,1 до 17 кг).

У 165 (59,1\%) пацієнтів діагностовано синдром Дауна.

Під час проведення обстеження для кожного пацієнта відзначали не тільки наявність супутньої хромосомної патології, а й ступінь недостатності спільного AB-клапана перед операцією. Гемодинамічно значуща недостатність спільного AB-клапана вважалась у випадках з помірним до вираженого або вираженим зворотним потоком крові на спільному АВ-клапані, визначеним у режимі кольорового доплера, та в пацієнтів I групи спостерігалась у 64 (26,1\%) випадках, у пацієнтів II групи - у 31 (91,2\%) випадку.

Усім пацієнтам I групи (збалансована АВК) виконана двошлуночкова корекція, яка полягала в закритті ДМПП та ДМШП і реконструкції спільного АВклапана. $188(67,4 \%)$ пацієнтам виконано первинну корекцію, 57 (20,4 \%) - двошлуночкову корекцію після звужування легеневої артерії (ЛА).

Пацієнти II групи з діагнозом «праводомінантна незбалансована $\mathrm{ABK}$ » мали різний ступінь гіпоплазії лівого шлуночка (ЛШ). Двом $(0,7$ \%) пацієнтам у період новонародженості з помірно вираженою гіпоплазією ЛШ, обструкцією вихідного тракту лівого шлуночка (ВТЛШ), коарктацією аорти (КоАо) та протокозалежною системною циркуляцією проведено I етап одношлуночкової корекції - модифікація операції Норвуда. Двом $(0,7 \%)$ пацієнтам виконано I етап одношлуночкової корекції (модифікація операції Норвуда) після початкового звужування ЛА, 16 (5,7 \%) пацієнтам 3 незбалансованою праводомінантною АВК, поєднаною 3 KоАо, - двошлуночкову корекцію після початкового звужування ЛА та усунення КоАо, 7 (2,5 \%) пацієнтам без протокозалежного системного кровообігу, з двома адекватними розмірами шлуночків у старшому віці - двошлуночкову корекцію. Із 7 пацієнтів з незбалансованою ліводомінантною АВК, у 3 (2,2 \%) випадках проведено півторашлуночкову корекцію та в 4 $(1,4 \%)$ - двошлуночкову корекцію.

Характеристику анатомічних особливостей вади проводили з використанням таких ЕхоКГ-показників:

1. Модифікований індекс атріовентрикулярного клапана (mAVVI). Із субкостальної по короткій осі ЛШ позиції обчислювали площу спільного АВ-клапана шляхом трасування його по контуру, після чого в передньозадньому напрямку проводили лінію між гребенем МШП та краєм інфундибулярної перегородки. Ця лінія розділяла спільний АВ-клапан на дві частини та розподіляла частину кожного клапана відповідному шлуночку. mAVVI розраховували 
як відношення площі лівої частини спільного АВклапана до загальної площі спільного AB-клапана [8]. Показник mAVVI в межах 0,4-0,6 визначав збалансовану АВK, $\geq 0,6$ - незбалансовану ліводомінантну АBK $\mathrm{i} \leq 0,4$ - незбалансовану праводомінантну АBK.

2. Кут припливу між правим і лівим шлуночками (RV/LV inflow angle). Кут формували шляхом проведення ліній від гребеня МШП до бокових точок кріплення спільного АВ-клапана. У збалансованій ABK кут припливу між правим і лівим шлуночками (RV/LV inflow angle) більш тупий, у незбалансованій - гостріший. Цей показник потенційно вказує на розмір ДМШП (чим гостріший кут, тим більший розмір ДМШП) та характеризує напрямок трансмітрального кровотоку до ЛШ, що є перпендикулярним у збалансованій АВК і тангенціальним у незбалансованій АВК [4, 6].

3. Індекс припливу лівого шлуночка (LVII). Розрахунок індексу припливу лівого шлуночка (LVII) проводили з використанням режиму кольорового доплера в апікальній 4-камерній проекції [14]. Спочатку у В-режимі двовимірної ЕхоКГ у кінці діастоли вимірювали діаметр анатомічного кільця лівого AВ-клапана між медіальною та латеральною точками його кріплення. У кольоровому доплері на рівні папілярних м'язів вимірювали найвужче місце кольорового припливного струменя (вторинний отвір). LVII розраховували як відношення діаметра вторинного отвору припливного кольорового струменя до діаметра анатомічного кільця. Значення LVII 0,5-0,55 характеризує безперешкодний приплив до ЛШ. Значення LVII $<0,5$ свідчить про морфологічні аномалії будови лівого AB-клапана та асоціюється з підвищеним ризиком смертності в пацієнтів з праводомінантною незбалансованою АВК після проведення двошлуночкової корекції [14].

4. Кінцево-діастолічну площу ЛШ та ПШ отримували шляхом трасування внутрішнього контуру ендокарда відповідного шлуночка в кінці діастоли в апікальній 4-камерній проекції.

5. Кінцево-систолічну площу ЛШ та ПШ отримували шляхом трасування внутрішнього контуру ендокарда відповідного шлуночка в кінці систоли в апікальній 4-камерній проекції.

6. Довжина ЛШ - відстань від основи АВ-клапана до верхівки серця в кінці діастоли в апікальній 4-камерній позиції.

7. Ширина ЛШ - відстань від гребеня МШП на боці ЛШ до його вільної стінки в апікальній 4-камерній позиції.

8. Довжина ПШ - відстань від основи АВ-клапана до верхівки серця в кінці діастоли в апікальній 4-камерній позиціі.
9. Ширина ПШ - відстань від гребеня МШП на боці ПШ до вільної стінки в апікальній 4-камерній позиції.

Комплексне трансторакальне ЕхоКГ обстеження дітей проводили на ультразвукових апаратах Philips IE 33 із застосуванням у новонароджених фазованих секторних датчиків S12-10, з частотою 10-12 МГц, у дітей віком понад 1 місяць - S8-3, із частотою 3-8 МГц.

Для статистичного аналізу використовували програму SPSS Statistics. Порівняння частот якісних показників у групах проводили шляхом побудови таблиць сполученості $2 \times 2$ із застосуванням критерію хі-квадрат або точного методу Фішера. Рівень достовірності р був двобічний, критерієм статистичної достовірності був $\mathrm{p}<0,05$ та вважався статистично значущим. Коефіцієнт кореляції Пірсона обчислювали, використовуючи парну делецію між показниками дисбалансу та розмірами шлуночків для об'єднаної групи пацієнтів. Значення коефіцієнта від 0 до 0,2 визначало дуже слабку кореляцію, до 0,5 - слабку кореляцію, до 0,7 вказувало на помірну кореляцію, а > 0,7 - на сильну кореляцію між зазначеними показниками.

Результати та обговорення. Під час проведення первинного обстеження, базуючись на вимірах mAVVI, у $245(87,8 \%)$ пацієнтів було діагностовано збалансовану ABK (середнє значення mAVVI 0,47 $\pm 0,09$ ), у 34 пацієнтів (12,2 \%) визначено певний ступінь дисбалансу спільного AB-клапана (середнє значення mAVVI $0,43 \pm 0,27)$. Проте в 10 випадках виникла невідповідність між первинним і передопераційним діагнозом та обраною хірургічною тактикою. Для 7 пацієнтів, яким на момент первинного обстеження діагностовано незбалансовану АВК, у 3 випадках діагноз змінили перед операцією та в 4 випадках у процесі лікування виникла зміна тактики хірургічного лікування (після початкового звужування ЛА проведена двошлуночкова корекція). У 3 пацієнтів з початковим діагнозом збалансована АВК, під час проведення хірургічного втручання відбулась зміна діагнозу та, як наслідок, виникла необхідність зміни хірургічної тактики (в одному випадку в немовляти з помірно вираженою гіпоплазією ЛШ, невеликою обструкцією ВТЛШ та КоАо після початково проведеного усунення КоАо та звужування ЛА на 5-у післяопераційну добу виникла потреба в проведенні І етапу одношлуночкової корекції - модифікації операції Норвуда; у 2 випадках аномалії лівого АВ-клапана виключили можливість проведення первинної двошлуночкової корекції). У більшості випадків mAVVI дозволяє ідентифікувати пацієнтів зі збалансованою та незбалансованою формами ABK, але не завжди допомагає самостійно визначати тактику хірургічного лікування.

Кореляційний аналіз ЕхоКГ-показників дисбалансу з вимірами «геометрії шлуночків» проводили для об’єднаної групи, яка складалась із 279 пацієнтів. Се- 
реднє значення модифікованого індексу АВ-клапанів (mAVVI) становило 0,45 $\pm 0,09$, середнє значення кута припливу між правим і лівим шлуночками (RV/LV inflow angle) - 125,7 $\pm 11,2$, середне значення індексу припливу ЛШ (LVII) було визначено як 0,54 $\pm 0,03$.

Кореляція тАVVI з вимірами «геометрії илуночків». Історично, оцінювання розміру шлуночків було основним фактором у визначенні хірургічної тактики лікування пацієнтів з незбалансованою АВК. ЕхоКГ-виміри, що характеризують розмір ЛШ та ПШ отримували з використанням В-режиму двовимірної ЕхоКГ. Оцінювали діаметри лівого та правого АВ-клапанів. Крім того, оцінювали кінцево-діастолічну та кінцево-систолічну площу ЛШ та ПШ. Вибір цих показників пояснюється технічною неможливістю достовірного оцінювання об'ємів шлуночків, особливо правого, двовимірною ЕхоКГ. У пацієнтів з АВК визначення об'єму шлуночка методом Сімпсона є не точним для правого $\mathrm{i}$, ймовірно, не точним для лівого, оскільки форма ЛШ при цій ваді відрізняється від форми звичайного шлуночка. Лінійні розміри в двовимірному режимі були доступні в усіх випадках і використовувалися для оцінювання відносних розмірів порожнин шлуночків, а не їх об'ємів.

У більшості пацієнтів I та II групи mAVVI передбачав відповідний розмір порожнини шлуночків.

Проте у 72 пацієнтів I групи (mAVVI 0,47 $\pm 0,09)$ на доопераційній ЕхоКГ у 58 (20,8 \%) випадках визначався помірно гіпоплазований ЛШ з ПШ-сформованою верхівкою серця та в 14 (5\%) випадках - помірно гіпоплазований ПШ із ЛШ-сформованою верхівкою серця.

У пацієнтів II групи (mAVV 0,43 \pm 0,27) у $4(11,8 \%)$ випадках, незважаючи на виражений дисбаланс спільного АВ-клапана, виявились два добре розвинені шлуночки.

mAVVI помірно корелює 3 діаметром кільця лівого AB-клапана та кінцево-діастолічною площею ЛШ і слабо корелює з діаметром кільця правого АВ-клапана та 3 кінцево-діастолічною площею ПШ (таблиця 1).

\section{Таблиця 1}

Кореляція $\mathrm{mAVVI}$ з розмірами, що характеризують «геометрію шлуночків»

\begin{tabular}{|c|c|c|}
\hline ЕхоКГ-показники & $\begin{array}{c}\text { Коефіцієнт } \\
\text { кореляції } \\
\text { Пірсона }\end{array}$ & $\mathbf{p}$ \\
\hline Діаметр правого АВ-клапана (см) & $0,240^{*}$ & $=0,001$ \\
\hline Діаметр лівого АВ-клапана (см) & $0,775^{*}$ & $<0,0001$ \\
\hline Кінцево-діастолічна площа ПШ (см²) & $0,383^{*}$ & $<0,0001$ \\
\hline Кінцево-діастолічна площа ЛШ (см²) & $0,531^{*}$ & $<0,0001$ \\
\hline
\end{tabular}

Примітка. *Кореляція значуща на рівні 0,01 (двобічна).
Помірна кореляція mAVVI з кінцево-діастолічною площею ЛШ та слабка кореляція mAVVI з кінцево-діастолічною площею ПШ свідчить про те, що диспропорція камер або невідповідність у розмірах порожнин ПШ та ЛШ у пацієнтів I групи у більшості випадків обумовлена впливом гемодинамічних факторів, а саме переважанням фізіології ДМПП, а не істинною гіпоплазією ЛШ. Об'ємне перевантаження ПШ призводить до ремоделювання порожнин серця, унаслідок чого відбувається зміна ступеня нахилу МШП в право-лівому напрямку, що сприяє появі «маленького» ЛШ, який фактично може розмістити значно більший об’єм [10].

На доопераційному етапі у 9 пацієнтів I групи кінцево-діастолічний об’єм (КДО) ЛШ був менше ніж 15 мл, доопераційний кінцево-діастолічний індекс (КДI) ЛШ коливався в межах 21,8-31,9 мл/м² (середній КДІ $24,0 \pm 18,8$ мл/ $\left.\mathrm{M}^{2}\right)$.

Після операції в усіх пацієнтів I групи КДО ЛШ збільшився із середнім значенням $30 \pm 12,7$ мл/м².

Усі показники відносного розміру ЛШ також значно збільшилися після операції. Збільшення розмірів ЛШ зі зміною нахилу МШП та збільшення довжини ЛШ відзначалось у більшості пацієнтів $(\mathrm{p}=0,03)$.

Крім того, помірна кореляція mAVVI з діаметром кільця лівого AB-клапана та помірна кореляція mAVVI 3 кінцево-діастолічною площею ЛШ вказує на те, що адекватний розмір лівого АВ-клапана, через який відбувається приплив до ЛШ шлуночка, суттєво впливає на його потенційний об'єм і свідчить про те, що він гіпотетично може бути придатним для двошлуночкової корекції. Тільки за оцінкою розміру шлуночка було б неправильно визначати дисбаланс АВ-клапанів у таких пацієнтів [9].

Гемодинамічні фактори сприяли виникненню невідповідності між розмірами шлуночків і розміром спільного АВ-клапана і для пацієнтів II групи. Виражена недостатність спільного AB-клапана, а також великий розмір ДМШП спричинює об'ємне навантаження на ЛШ. Таке об’ємне навантаження змінює розміри ЛШ перед операцією і призводить до збільшення морфометричних показників, ніж це було б, якщо б цих факторів не існувало. Така невідповідність спостерігалась у 3 пацієнтів з незбалансованою АВК, які мали виражений дисбаланс спільного АВ-клапана і нормальний розмір порожнин ЛШ та ПШ. У всіх трьох були відзначені великі розміри ДМШП, а 2 з 3 мали виражену недостатність спільного АВ-клапана перед операцією.

Кореляція RV/LV inflow angle з вимірами «геометріï шлуночків». RV/LV inflow angle помірно корелює з діаметром кільця лівого AB-клапана та з діаметром кільця правого AВ-клапана і слабо корелює з кінцево-діастолічною площею ЛШ та 3 кінцево-діастолічною площею ПШ (таблиця 2). 
Шаповал Л.А. / Власний досвід ехокардіографічного оцінювання ступеня асиметрії атріовентрикулярного...

\section{Таблиця 2}

Кореляція RV/LV inflow angle з розмірами, що

характеризують «геометрію шлуночків»

\begin{tabular}{lcc} 
ЕхоКГ-показники & $\begin{array}{c}\text { Коефіцієнт } \\
\text { Пірсона }\end{array}$ & $\mathbf{p}$ \\
\hline Діаметр правого АВ-клапана (см) & $0,775^{*}$ & $<0,0001$ \\
\hline Діаметр лівого АВ-клапана (см) & $0,861^{*}$ & $<0,0001$ \\
\hline Кінцево-діастолічна площа ПШ $\left(\mathrm{cm}^{2}\right)$ & $0,254^{*}$ & $=0,001$ \\
\hline Кінцево-діастолічна площа ЛШ $\left(\mathrm{cm}^{2}\right)$ & $0,333^{*}$ & $<0,0001$
\end{tabular}

Примітка. *Кореляція значуща на рівні 0,01 (двобічна).

Встановлений взаємозв'язок підтверджує висновок про те, що RV/LV inflow angle характеризує напрямок кровотоку, спрямованого до шлуночка і ніяк не характеризує розмір клапана або розмір шлуночка. Оскільки розмір ЛШ пояснюється ступенем заповнення його під час діастоли, відсутність кореляції RV/LV inflow angle 3 розміром ЛШ свідчить про те, що при оцінюванні цього показника не враховується ступінь припливу до шлуночка в пацієнтів з різними значеннями mAVVI.

Корелячія LVII з вимірами «геометрії шлуночків». Виявлена слабка кореляція LVII з кінцево-діастолічною площею ЛШ та слабка кореляція LVII з діаметром кільця лівого AB-клапана. Відсутня кореляція LVII з кінцево-діастолічною площею ПШ та діаметром кільця правого AВ-клапана (таблиця 3).

Індекс припливу ЛШ (LVII) характеризує приплив до ЛШ, вказуючи на обструкцію для припливу скрізь, де вона може перебувати (як на рівні спільного ABклапана, так і на рівні підклапанного простору) [5].

LVII характеризує відносний розмір потоку в кольоровому доплері через лівий $\mathrm{AB}-$ клапан та забезпечує інформацією про ефективний отвір клапана відносно розміру його анатомічного кільця [8]. Дисплазія лівого AB-клапана, аномалії папілярних м'язів і недостатність спільного AB-клапана спостерігались у пацієнтів обох груп. Однак значно вищий відсоток пацієнтів II групи мали порушення структурної будови та гемодинамічно значущу недостатність лівого АВ-клапана порівняно з пацієнтами I групи ( $\mathrm{p}=0,03)$.

Отримана слабка кореляція LVII з діаметром кільця лівого AB-клапана свідчить про наявність, хоч і незначної, відповідності між розміром і функцією лівого AB-клапана, що може бути важливим при розгляді цих ознак разом.

Хірургічний поділ спільного АВ-клапана під час виконання двошлуночкової корекції має забезпечити формування двох достатньо безперешкодних вхідних отворів AВ-клапанів без виникнення в післяопераційному періоді клінічно важливої недостатності або стенозу клапана. При визначенні можливості проведення двошлуночкової корекції слід враховувати не тільки

\section{Таблиця 3}

Кореляція LVII з розмірами, що характеризують «геометрію шлуночків»

\begin{tabular}{lcc} 
ЕхоКг-показники & $\begin{array}{c}\text { Коефіцієнт } \\
\text { Пірсона }\end{array}$ & $\mathbf{p}$ \\
\hline Діаметр правого АВ-клапана (см) & 0,067 & $=0,377$ \\
\hline Діаметр лівого АВ-клапана (см) & $0,175^{*}$ & $=0,021$ \\
\hline Кінцево-діастолічна площа ПШ $\left(\mathrm{cm}^{2}\right)$ & 0,097 & $=0,203$ \\
\hline Кінцево-діастолічна площа ЛШ $\left(\mathrm{cm}^{2}\right)$ & 0,101 & $=0,990$
\end{tabular}

Примітка. *Кореляція значуща на рівні 0,05 (двобічна).

розмір спільного $\mathrm{AB}-$ клапана, а і його морфологію та функцію.

Результати нашого дослідження збігаються з літературними даними. На сьогодні не ідентифіковано групи показників з точними відсіками, що дають змогу визначити відповідну тактику хірургічного лікування в пацієнтів з різними анатомічними варіантами АВК. У дослідженні Meza J. M. et al. [11] було оцінено кореляцію mAVVI, RV/LV inflow angle та LVII у великій групі пацієнтів. Ці показники погано корелюють або зовсім не корелюють між собою. Відсутня суттєва кореляція між mAVVI та RV/LV inflow angle і причиною цьому є те, що вони оцінюють різні речі (дисбаланс на рівні спільного АВ-клапана і розмір ДМШП відповідно). Встановлено, що RV/LV inflow angle лише помірно корелює з LVII, і це тому, що на обидва параметри впливає розмір ДМШП. Аналогічно, помірний ступінь кореляції, що виявлений між mAVVI і LVII, пояснюється тим, що на обидва показника впливає розмір лівого компонента спільного АВ-клапана. Крім того, описано інші показники, які потрібно враховувати під час оцінювання ступеня дисбалансу та визначення відповідної тактики хірургічного лікування. Цей довгий список включає (але не обмежується): індекс порожнини шлуночків [8]; співвідношення довжин шлуночків [2]; об'єми шлуночків; верхівкоформування шлуночка; overriding та/або straddling AB-клапана [1]; z-score AB-клапанів [12]; протокозалежність системної циркуляції; зміщення міжпередсердної та/або міжшлуночкової перегородки $[10,13]$; недостатність спільного АВ-клапана; легеневу гіпертензію. Асоційовані вади, такі як КоАо або подвійний вихід великих судин із ПШ [3], також можуть змінювати фізіологію АВК і мають бути враховані при виборі оптимальної хірургічної тактики.

Висновок. Результати нашого дослідження підтверджують велику різноманітність спектра анатомічних варіантів АВК. Нині метод ехокардіографії є загальноприйнятим методом доопераційної діагностики пацієнтів з такою складною патологією з високою чутливістю та специфічністю, що дозволяє обгрунтувати та планувати хірургічне лікування вади в оптимальні 
терміни. Проте ЕхоКГ-показники, що характеризують симетричність АВ-з'єднання, мають слабку або помірну кореляцію з вимірами «геометрії шлуночків», що свідчить про те, що жоден з цих показників не слід використовувати самостійно при визначенні ступеня збалансованості та вибору тактики хірургічного лікування в кожному окремому випадку.

\section{Список використаних джерел References}

1. Nathan M, Liu H, Pigula FA, Fynn-Thompson F, Emani S, Baird CA, et al. Biventricular conversion after singleventricle palliation in unbalanced atrioventricular canal defects. Ann. Thorac. Surg. 2013;95:2086-95. https://doi. org/10.1016/j.athoracsur.2013.01.075

2. Delmo Walter EM, Ewert P, Hetzer R, Hobler M, AlexiMeskishvili V, Lange P, Berger F. Biventricular repair in children with complete atrioventricular septal defect and a small left ventricle. Eur. J. Cardiothorac. Surg. 2008;33:40-7.

3. Shuhaiber JH, Ho SY, Rigby M, Sethia B. Current options and outcomes for the management of atrioventricular septal defect. Eur. J. Cardiothorac. Surg. 2009;35:891-900. https://doi.org/10.1016/j.ejcts.2009.01.009

4. Lugones I, Biancolini MF, Biancolini JC, Dios AMS, Lugones G. Feasibility of Biventricular Repair in Right Dominant Unbalanced Atrioventricular Septal Defect: A New Echocardiographic Metric to Refine Surgical Decision-Making. World J. Pediatr. Congenit. Heart. Surg. 2017;8:460-7.https://doi.org/10.1177/2150135117716420

5. Jegatheeswaran A, Pizarro C, Caldarone CA, Cohen MS, Baffa JM, Gremmels DB, et al. Echocardiographic definition and surgical decision-making in unbalanced atrioventricular septal defect: a Congenital Heart Surgeons' Society multiinstitutional study. Circulation. 2010;122:209-15. https://doi.org/10.1161/CIRCULATIONAHA.109.925636

6. Cohen MS, Jegatheeswaran A, Baffa JM, Gremmels DB, Overman DM, Caldarone CA, et al. Echocardiographic features defining right dominant unbalanced atrioventricular septal defect: a multi-institutional Congenital Heart Surgeons' Society study. Circ. Cardiovasc. Imaging. 2013;6:508-13. https://doi.org/10.1161/ CIRCIMAGING.112.000189
7. Buratto E, Ye XT, King G, Shi WY, Weintraub RG, d'Udekem Y, et al. Long-term outcomes of single-ventricle palliation for unbalanced atrioventricular septal defects: Fontan survivors do better than previously thought. J. Thorac. Cardiovasc. Surg. 2017;153:430-8. https://doi. org/10.1016/j.jtcvs.2016.09.051

8. Cohen MS, Jacobs ML, Weinberg PM, Rychik J. Morphometric analysis of unbalanced common atrioventricular canal using two-dimensional echocardiography. J. Am. Coll. Cardiol. 1996;28:1017-23. https://doi.org/10.1016/s0735-1097(96)00262-8

9. van Son JA, Phoon CK, Silverman NH, Haas GS. Predicting feasibility of biventricular repair of rightdominant unbalanced atrioventricular canal. Ann. Thorac. Surg. 1997;63:1657-63.

10. Ahmad Z, Lim Z, Roman K, Haw M, Anderson RH, Vettukattil $\mathrm{J}$. The angulation of the septal structures impacts ventricular imbalance in atrioventricular septal defects with a common atrioventricular junction. Cardiol. Young. 2016;26:321-6. https://doi.org/10.1017/ S1047951115000219

11. Meza JM, Devlin PJ, Overman DM, Gremmels D, Baffa G, Cohen MS, et al. The Congenital Heart Surgeon's Society complete atrioventricular septal defect cohort: Baseline, preintervention echocardiographic characteristics. Semin. Thorac. Cardiovasc. Surg. 2019 Spring;31(1):80-86. https://doi.org/10.1053/j.semtcvs.2018.02.004

12. Foker JE, Berry JM, Vinocur JM, Harvey BA, Pyles LA. Two-ventricle repairs in the unbalanced atrioventricular canal defect spectrum with midterm follow-up. J. Thorac. Cardiovasc. Surg. 2013;146:854-60. https://doi. org/10.1016/j.jtcvs.2013.05.013

13. Overman DM, Dummer KB, Moga FX, Gremmels DB. Unbalanced atrioventricular septal defect: defining the limits of biventricular repair. Semin. Thorac. Cardiovasc. Surg. Pediatr. Card. Surg. Annu. 2013;16:32-6. 10.1053/j. pcsu.2013.01.009

14. Szwast AL, Marino BS, Rychik J, Gaynor JW, Spray TL, Cohen MS. Usefulness of left ventricular inflow index to predict successful biventricular repair in right-dominant unbalanced atrioventricular canal. Am. J. Cardiol. 2011;107:103-9. 10.1016/j.amjcard.2010.08.052

\title{
Actual Experience of Echocardiographic Evaluation of the Asymmetry of Atrioventricular Septal Defect in Patients with Different Anatomical Variants of Atrioventricular Septal Defect in the Choice of Optimal Surgical Approach
}

\author{
Shapoval L. A. ${ }^{1}$, Rudenko N. M. ${ }^{1,2}$, Dovgan O. M. ${ }^{1}$, Yemets I. M. ${ }^{1}$ \\ ${ }^{1}$ Ukrainian Children's Cardiac Centre, Kyiv, Ukraine \\ ${ }^{2}$ Shupyk National Medical Academy of Postgraduate Education, Kyiv, Ukraine
}

\begin{abstract}
Atrioventricular septal defect (AVSD) is a complex congenital heart defect caused by the abnormal structure of atrioventricular septum above and below the level of atrioventricular (AV) valves. Such a disturbance of the structure leads to the formation of a common opening of the $\mathrm{AV}$ valve which connects both atria with both ventricles. As a rule, $\mathrm{AV}$ junction is symmetrical, which results in an even and balanced flow of blood to each ventricle. However, there is a spectrum of nonuniform AV junction which is associated with hypoplasia of the left or right ventricle. In such cases, the AVSD is defined
\end{abstract}


as unbalanced and characterized by varying degrees of $\mathrm{AV}$ junction displacement, hypoplasia of one of the ventricles and anomalies of the valve structures of the common $\mathrm{AV}$ valve. The main task in determining the imbalance of $\mathrm{AV}$ junction is to predict the left ventricle capacity to maintain systemic circulation, which is important in choosing the optimal surgical approach. The current trend is to combine new concepts and diagnostic criteria already described in order to determine the best way of treating children with such a complex congenital heart anomaly.

The objective is to analyze the main echocardiographic indicators that determine the imbalance in patients with different anatomical variants of AVSD and to reveal correlation of these indicators with the dimensions which characterize the "ventricular geometry" in accordance with the chosen surgical approach.

Material and methods. From January 2014 to December 2018, 279 patients with different anatomic variants of AVSD underwent examination and surgical treatment. Balanced AVSD was diagnosed in 245 (87.8\%) patients (group I), the remaining $34(12.2 \%)$ patients had a certain degree of imbalance in the common AV valve (group II), of these $27(9.8 \%$ ) had unbalanced right-dominant AVSD, and 7 (2.5\%) had unbalanced left-dominant AVSD.

For the determination of anatomical features, the following echocardiographic parameters were used: modified atrioventricular valve index (mAVVI), right and left ventricular inflow angle (RV/LV inflow angle), left ventricular inflow index (LVII), end-diastolic area of LV and RV, end-systolic area of LV and RV, and linear dimensions of both ventricles and AV valves.

Results. All patients in group I underwent biventricular repair. 188 (67.4\%) patients had primary repair, 58 (20.4\%) patients had total repair after diminution of the pulmonary artery. Patients of group II diagnosed with right-dominant unbalanced AVSD had various degrees of LV hypoplasia. Four patients underwent modified Norwood operation as a stage I of single-ventricular repair. In 23 patients with right-dominant AVSD, total repair was performed. Of 7 patients with unbalanced left-dominant AVSD, 3 (2.2\%) had one and a half ventricular repair and 4 (1.4\%) underwent biventricular repair of the anomaly.

Comparing different echocardiographic imbalance indices, it was found that mAVVI moderately correlated with the diameter of the left $\mathrm{AV}$ valve annulus $(\mathrm{r}=0.775, \mathrm{p}<0.0001)$ and with the end-diastolic area of the $\mathrm{LV}(\mathrm{r}=0.531, \mathrm{p}<0.0001)$, and slightly correlated with the diameter of the right $\mathrm{AV}$ valve annulus $(\mathrm{r}=0.23, \mathrm{p}=0.0013)$ and with the end-diastolic area of the RV $(r=0.240, p=0.001)$. The RV/LV inflow angle moderately correlated with the diameter of the left AV valve annulus and the diameter of the right $A V$ valve annulus $(r=0.861, p<0.0001$ and $r=0.775, p<0.0001$, respectively) and does not significantly correlate with the end-diastolic area of the LV and the end-diastolic area of the RV. The slight LVII correlation with LV end-diastolic area $(r=0.101, p=0.880)$ and slight LVII correlation with the diameter of the left $\mathrm{AV}$ valve annulus were found. LVII had moderate correlation with the diameter of the right $A V$ valve annulus $(r=0.175, p=0.021)$. There is no LVII correlation with the end-diastolic area of the RV.

Conclusion. Comparing different echocardiographic imbalance indices, it was found that mAVVI moderately correlated with the diameter of the left $\mathrm{AV}$ valve annulus imbalance indices have slight or moderate correlation with ventricular dimensions, indicating that none of these indicators should be used independently in determining the degree of balance and the choice of surgical approach in patients with different anatomical variants of AVSD.

Keywords: unbalanced atrioventricular septal defect, modified index of atrioventricular valves, left ventricle inflow index, $R V / L V$ inflow angle.

Стаття надійшла в редакцію 06.08.2019 p. 